\title{
ON EUMENES ALLUAUDI PEREZ, A PRECINCTIVE WASP OF THE SEYCHELLES (HYMENOPTERA).
}

By J. Bequaert,

American Museum of Natural History, New York City.

In my Catalogue of Ethiopian Diplopterous Wasps, published in $1918,{ }^{1}$ I have attempted to correlate the various described forms of African Eumenes. In many cases, where specimens were not available for study, my conclusions were based on such inferences as could be made from published accounts, and were therefore only tentative. Eumenes alluaudi J. Pérez, ${ }^{2}$ for instance, I regarded at the time as one of the color variants of Eumenes lepeleterii Saussure, to which it was said to be related by the author of the species. Through the courtesy of Mr. A. S. Rohwer, I recently had opportunity to examine a series of specimens of $E$. alluaudi in the U. S. National Museum collection, and was surprised to find that this wasp is structurally very distinct from any of its congeners. Since it apparently is restricted to a very small range in the Seychelles and neighboring islands, and thus affords a typical illustration of the effects of oceanic isolation upon the appearance and preservation of specific characters, it may be useful to redescribe the form and to figure some of its most noteworthy peculiarities.

Female. Length (head+thorax+tergites $1+2) 21 \mathrm{~mm}$.

Decidedly more slender than $E$. maxillosus, strikingly so in the abdomen. Head (Fig. 1b) from front view about as high as broad, due to the lengthening of the clypeus. Clypeus distinctly higher than broad; its apical free portion a little longer than its basal part and with more deeply concave sides than in E. maxillosus; its apical margin almost straight, slightly curved inward, with pronounced, but blunt lateral angles. Vertex without fovea. Eyes bare. Posterior ocelli about as far from each other as from the eyes. Mandibles shaped much as in E. maxillosus; long and slender, beak-like, the inner margin with three slight notches; near the base of the inner margin an indication of the raised fold which is so prominent in the male. Antennæ and mouth-

1 Bull. American Mus. Nat. Hist., 39, 1918, pp. 274-283.

${ }^{2}$ Ann. Soc. Ent. France, 64, 1895, p. 206. 
parts as in E. maxillosus. Shape and structure of thorax and legs also as in that species. Middle tibiæ with one spur. Abdomen more slender than in E. maxillosus, though of the same general shape. The basal, narrow portion of the petiole is fairly parallelsided and about as long as, or but little shorter than, its apical, broadened part; the spiracles are prominent, placed a little beyond half the length of the petiole; the broadened, posterior portion

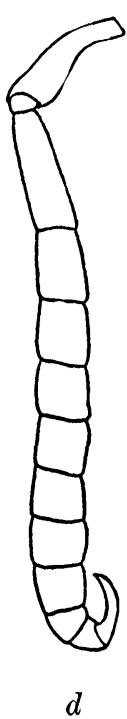

$d$
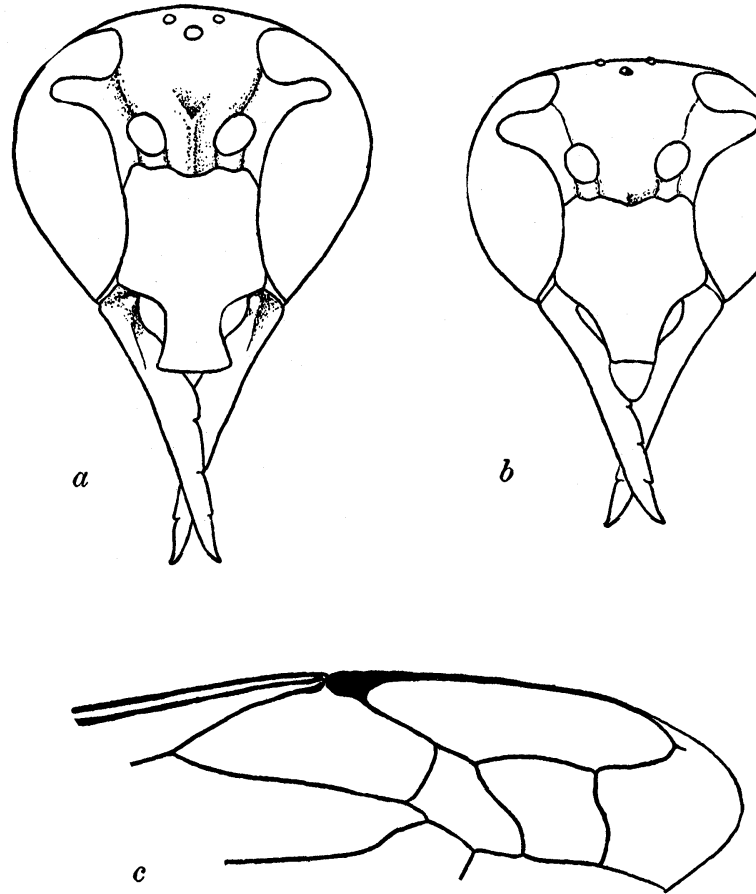

Fig. 1. Eumenes alluaudi J. Pérez. a, head of male in front view; b, head of female in front view; c, part of fore wing; $d$, antenna of male.

is nearly parallel-sided, but it has expanded apical angles as in E. maxillosus. In profile the posterior, broad portion of the petiole is less swollen and slopes more gradually toward the hind margin than in $E$. maxillosus. Second abdominal segment also more slender than in that species, with simple hind margin; its sternite regularly convex, but little if any flattened in the middle, never saddle-shaped. Fore wing (Fig. 1c) with the third cubital cell 
much longer than in E. maxillosus; on the radial cell it is slightly shorter than high and about the length of the second cubital cell on the cubitus.

Punctation mainly as in E. maxillosus. The clypeus, however, is not dull and feebly shagreened as in that species, but shiny, varnished, with hardly any sculpture-that can be discerned with a hand lens, except for a very few, scattered, minute dots toward the sides. The thorax is also somewhat more finely sculpturea than in E. maxillosus. Pubescence a little more abundant than in that species, especially on the under side of the abdominal petiole.

Black, abundantly marked with chrome-orange (nearest orange rufous of Ridgway's color nomenclature). Head almost entirely chrome-orange, with the exception of the inferior margins of the eyes at the extreme base of the mandibles, the posterior half of the temples, the occiput, the vertex, and the emargination of the eyes, which are black. Antennæ orange-yellow, somewhat darkened above. Thorax chrome-orange; mesonotum black, except for a narrow, comma-shaped orange spot placed on each side of the middle line, close to the pronotum; most of the thoracic sutures more or less tinged with black. Legs chrome-orange. Abdominal petiole chrome-orange, except at its base, which is black. Remainder of the abdomen velvety pitch-black, except its last sternite, which is more or less ferruginous. Wings almost uniformly smoky, with a strong purplish effulgence.

Male. Length (head+thorax + tergites $1+2) 23 \mathrm{~mm}$.

Differs from the female only in the secondary sexual characters. Clypeus much higher than broad, of a very peculiar shape (Fig. $1 a)$ : its basal portion is nearly rectangular and somewhat longer than its apical, free part; the latter forms a rectangular, projecting plate, abruptly narrowed from the basal portion and slightly widened at its feebly convex or nearly straight, apical margin; the lateral angles of the apical margin are blunt but prominent, bearing short, raised ridges. The inner margin of the mandibles has, near its base, a strongly raised, somewhat tuberculate fold. Antennæ (Fig. $1 d$ ) much as in the male of E. maxillosus; their last, hook-like joint intermediate in shape between that of E. lepeleterii and $E$. caffer, being long, almost uniformly thick for the greater 
part of its length, feebly and gradually thickened toward its base, rather rapidly pointed at its apex, which is sharp and feebly curved; it can be folded into a small, deep, rounded pit at the extreme base of the under side of the tenth joint. Abdominal sternites three to seven more abundantly hairy than in E. maxillosus.

General coloration as in the female, but the posterior half of the petiole of the abdomen dorsally with a broad, heart-shaped, black mark (a black triangle with the apex directed posteriorly and the anterior base deeply emarginate). The last three abdominal sternites more or less ferruginous.

This species is evidently allied to $E$. maxillosus, but the male possesses such striking morphological peculiarities that it cannot be regarded as a color race of that species. I have been unable to find any close relative among the many species of Eumenes known from the Oriental and Indo-malayan regions.

The five females and two males seen by me are all colored much alike and come from the following localities: Mahé Island, Seychelles, 3 \& $\%$; Seychelles, $1 \%$ and 1 î ; Glorioso Islands, $1 \%$ and $1 \%$. All collected by Dr. W. L. Abbott.

$E$. alluaudi is known thus far only from the Seychelles and the Glorioso Islands (about 120 miles off the northern point of Madagascar, in the Strait of Mozambique), where no other species of the genus has thus far been collected. Very likely it is to be found also in the Comoros, although typical $E$. maxillosus alone has been recorded there. It evidently does not occur on Madagascar, which possesses two color forms of $E$. lepeleterii (pensilis Saussure and guerini Saussure) and one of E. maxillosus (reginus Saussure), all peculiar to that island, in addition to typical $H$. maxillosus.

J. Pérez described E. alluaudi originally from Mahé. Cameron ${ }^{1}$ recorded it as common on Praslin and Mahé. G. Meade Waldo, ${ }^{2}$ who gives Silhouette and Dennis Island as additional localities, notes that it "very often makes its cells in rooms; it was not observed in the highest forests." Its habits are thus evidently similar to those of E. maxillosus. The same author comments as follows upon the reddish chrome color pattern of $E$. alluaudi being

1 Trans. Linn. Soc. London, Zool., (2) 12, 1907, p. 71.

2 Ibid., (2) 15, 1912, p. 43. 
repeated in Odynerus seychellensis Dalla Torre and Crabro scotti Turner: "It would seem that the insects with markings of this color are indigenous to the Seychelles, since none of the three species mentioned are found outside the group; on the other hand the widely spread and imported species preserve their normal type of marking."

\section{EXCHANGE NOTICE.}

WANTED :-Species of Tetraopes from all sections of the country, in exchange for Coleoptera of this region. Wm. J. Clench, Bussey Institution, Boston 30, Mass. 

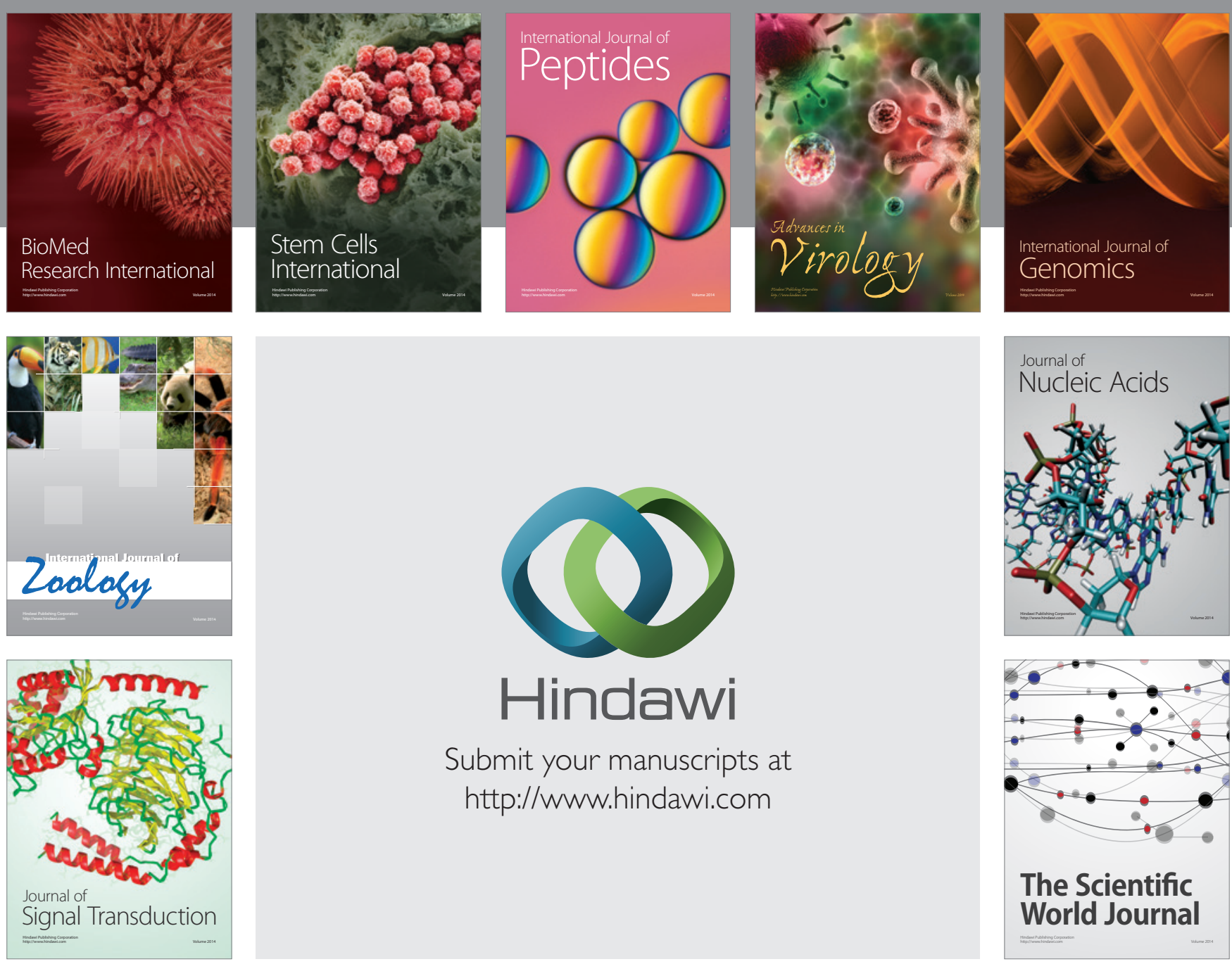

Submit your manuscripts at

http://www.hindawi.com
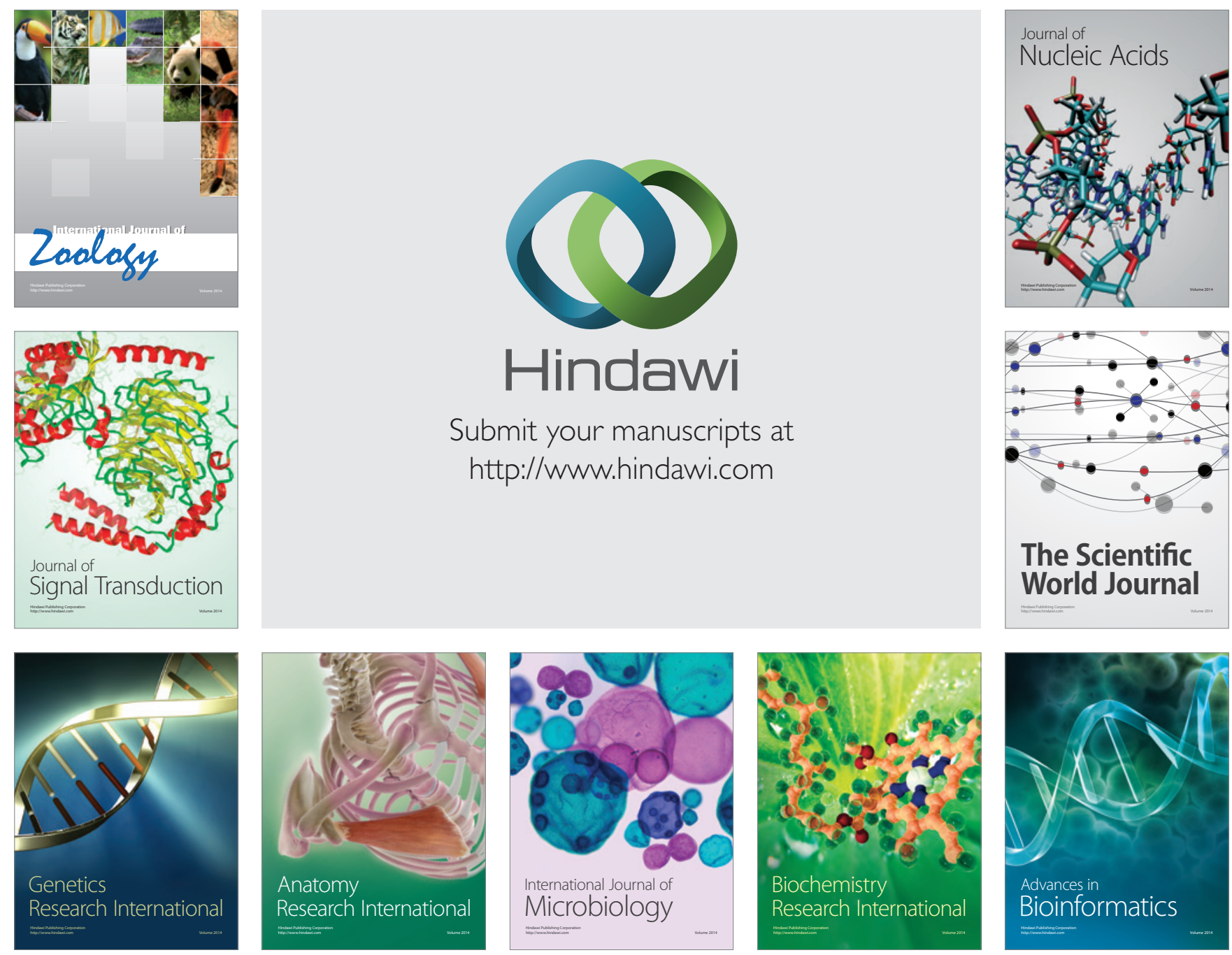

The Scientific World Journal
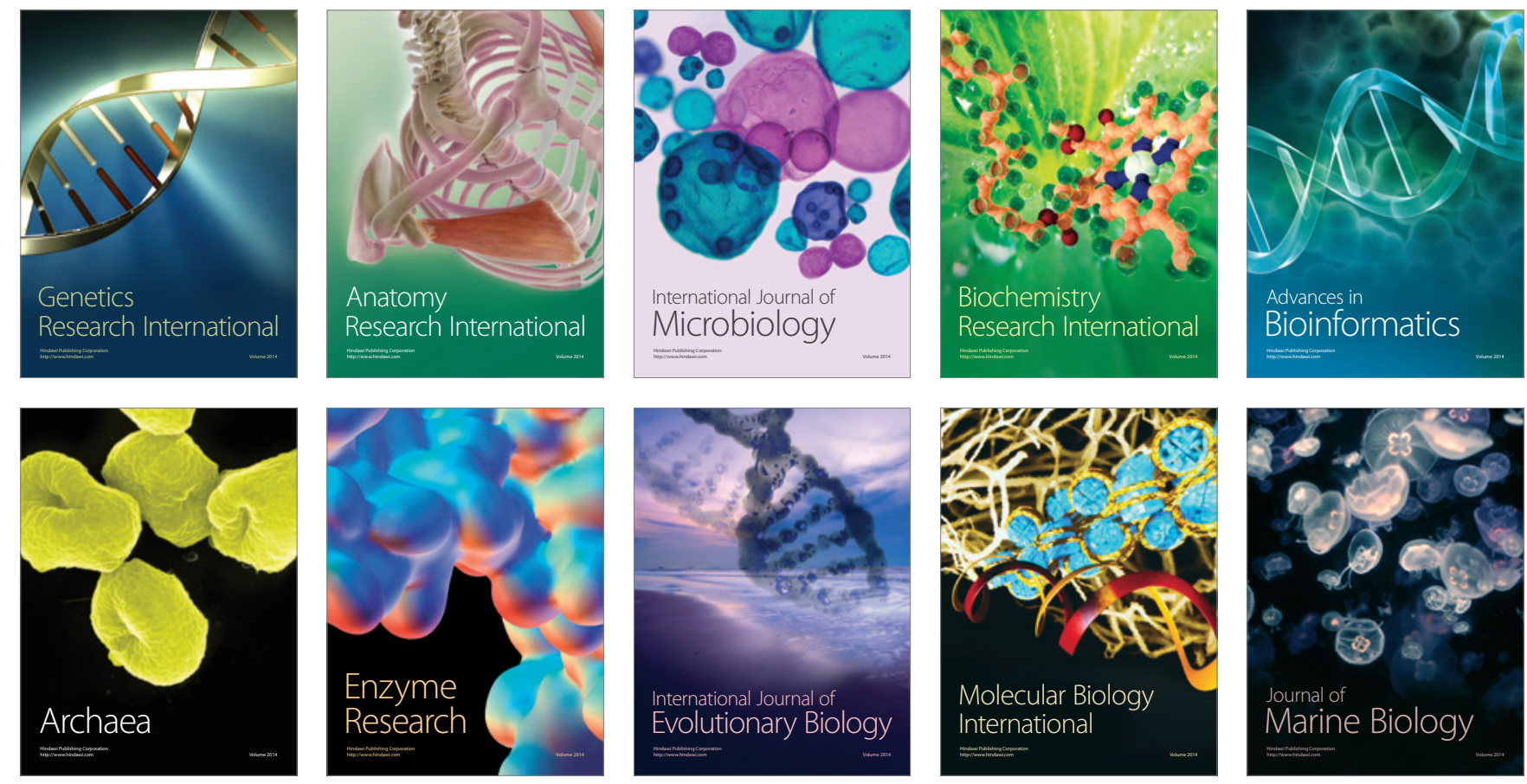